\title{
Logistic as a Tool to Achieve Sustainable Development Goals
}

\author{
O. Yu. Matantseva ${ }^{1,2}$, I. V. Spirin ${ }^{2,}$, N. M. Ulitskaya ${ }^{1}$, I. S. Kazantsev ${ }^{2}$ \\ ${ }^{1}$ Moscow Automobile and Road Construction State Technical University (MADI), Moscow, Russia \\ ${ }^{2}$ JSC Scientific Research Institute of Motor Transport (JST Company NIIAT), Moscow, Russia \\ ${ }^{*}$ Corresponding author.Email: ivspirin@yandex.ru
}

\begin{abstract}
A necessary condition for achieving the goals of sustainable development of civilization - with improving the economy. Logistics is one of the most urgent areas of increasing the efficiency of social production. The level of development of logistics largely determines not only the economic results of economic activity, but also has a direct impact on the preservation of natural heritage, contributes to the leveling of social differences. The impact of logistics on the achievement of the global sustainable development goals set by the United Nations has not been sufficiently studied. Therefore, the purpose of this article is to establish the influence of logistics on the achievement of sustainable development goals. Based on the grouping of sustainable development goals by focus on achieving the main results, the authors substantiated the cause-and-effect relationships of the impact of logistics on the achievement of these goals and show the mechanisms for implementing this impact. The instrumentalities of applying the logistic approach to achieve the planned values of indicators of achieving the established target indicators.
\end{abstract}

Keywords: sustainable development, sustainable development goals, logistics, impact mechanism, grouping of goals.

\section{INTRODUCTION}

Traditionally, the development of society has been associated with economic growth. However, at present, humanity is faced with a crisis of the mercantilist model of the economy, built on obtaining an entrepreneurial result according to the "expenses - income - profit" scheme. Therefore, the most important non-systemic effects are overlooked, the value of which can be many times higher than the profit of investors. In particular, this applies to urban passenger transport systems [1]. Environmental problems are well known, largely resulting from the unacceptable interference of people in natural mechanisms [2]. The aggravation of social contradictions is due to the uneven development of various countries, territories and settlements, the aggravation of economic and environmental problems. Social contradictions are especially acute in cities, where more than half of humanity lives overcrowded. Cities occupy less than $1 \%$ of the land area, but they produce about $80 \%$ of GDP, consume about $90 \%$ of all resources and energy. Therefore, cities are point concentrators of anthropogenic impact on the environment [3].
Awareness of the need to address these global challenges and address inconsistencies led to a concept of sustainable development (Sustainable development - the SD), developed based on the research of thousands of scientists from different countries and was officially declared as a global development trends of the UN resolutions, to which the Russian Federation [4, 5]. Sustainable development is a form of practical implementation of the noospheric doctrine on the inadmissibility of uncontrolled anthropogenic impact on the environment, which can lead to the destruction of the latter. Sustainable development is understood as harmonized economic, social development in conditions of environmental preservation in the interests of the present and future generations $[1$, 2].

Naturally, one of the foundations of SD is to improve the economy. At present, the center for the formation of costs in the implementation of production and economic activities has moved from the sphere of production to the sphere of circulation of the mass of commodities. This became the main reason for the spread of logistics as a direction of practical activity and scientific research, the subject of which is the rationalization (optimization) of the flows of resources created by people in space and time. Logistics has become the main focus for increasing 
economic efficiency. The logistic approach allows you to optimize the circulation of various resources while minimizing energy costs and harmful emissions [6].

The potential for the impact of logistics on SD is not well understood. Therefore, the purpose of this article is to establish the possible directions and consequences of the impact of logistics on the achievement of SD goals.

\section{RESEARCH QUESTIONS}

Grouping SD goals by focus on achieving major globally significant results.

Justification of the causal relationships of the impact of logistics on the achievement of SD objectives and the possible limits of such impact.

Establishing a mechanism for the impact of logistics on the achievement of SD objectives.

\section{MATERIALS AND METHODS}

The materials for the research were the conceptual provisions of SD and the results of the frequency and logical expert analysis.

The methodology of these study is based on knowledge and developments in the fields of economic theory, logistics, management, ecology, sociology, benchmarking of the use of a logistic approach to solving sustainable development problems, logical and expert analysis. Published results obtained earlier by various researchers are used.

\section{RESULTS OF RESEARCH}

\subsection{Grouping Sustainable Development Goals by Results Achieved}

Seventeen globally significant goals of sustainable development are established by the UN resolution [7]. The international obligation of each of the states that adopted this document (including the Russian Federation) is the development and implementation of public policy measures aimed at the systematic achievement of SD goals in accordance with the national specifics and peculiarities of building public relations in each of the countries, as well as friendly assistance to the achievement of these goals on a global scale.

SD goals have different focus on achieving specific results. The list of tasks that must be solved to achieve the SD goals is presented in [7]. The logical analysis of the content of the target results showed that, according to the sphere of the affected relations, they can be subdivided into four groups (Figure 1):

humanitarian results, aimed mainly at the personality of each man, are into account his social environment (family, colleagues, neighbors, etc.), economic results, expressed in the achievement of a new level of material well-being, which ensures a further increase in the quality of life,

social and political results that provide personally and socially significant guarantees and freedoms, security and a sense of security, environmental results that create the prerequisites for improving the environment, preserving natural heritage, including for future generations.

The division of 17 SD goals into four groups was performed by the authors using a frequency and logical analysis of expert opinions (we used the results of a questionnaire survey of 43 experts who are specialists in the fields of SD, logistics, economics, and transport). The assignment of goals to a specific group does not limit the possibility of the simultaneous impact of the corresponding event on the achievement of goals assigned to other groups. The essence of the logistic impact on the achievement of SD goals has both individual and common features characteristic of each of the four groups (see 4.2 below).

The review [8] presents an analysis of the published in 2015-2020. 101 articles exploring the role of business in realizing SD goals. Achieving economic goals is directly associated with the implementation of logistically rational management decisions, since logistics is aimed at reducing costs in the field of circulation.

An important feature of logistics is its organic connection with the preservation of the environment. Every logistically sound decision always leads to proportional positive shifts in environmental well-being. This is because the criterion for choosing a logistically rational management solution option is to minimize transport or warehouse work.

As a result, transportation, storage operations, energy consumption and reduction of emissions into the environment are minimized. Figuratively speaking, logistics is the sister of ecology [9].

Achieving goals G 1 and G 2 is directly linked to the implementation of logistically sound policies. According to the research of Indian scientists, the problems of ensuring food security can be largely solved through the correct distribution of subsidies along the elements of the supply chain. These problems are largely explained by ineffective logistic interaction between participants in supply chains, and a low level of organization of transport and warehouse systems. 
G1. End poverty in all its forms everywhere

Humanity goals:

G2. End hunger, achieve food security and improved nutrition and promote sustainable agriculture

G3. Ensure healthy lives and promote well-being for all at all ages

G4. Ensure inclusive and equitable quality education and promote lifelong learning opportunities for all

G5. Achieve gender equality and empower all women and girls

G10. Reduce inequality within and among countries

Economics goals:

G8. Promote sustained, inclusive and sustainable economic growth, full and productive employment and decent work for all G9. Build resilient infrastructure, promote inclusive and sustainable industrialization and foster innovation

G12. Ensure sustainable consumption and production patterns

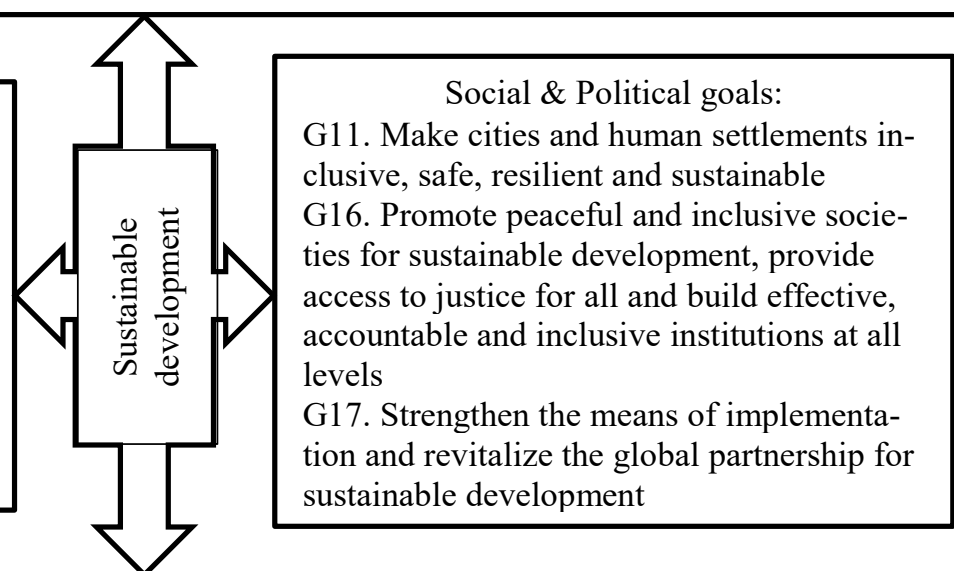

Environmental goals:

G6. Ensure availability and sustainable management of water and sanitation for all

G7. Ensure access to affordable, reliable, sustainable and modern energy for all

G13. Take urgent action to combat climate change and its impacts

G14. Conserve and sustainably use the oceans, seas and marine resources for sustainable development

G15. Protect, restore and promote sustainable use of terrestrial ecosystems, sustainably manage forests, combat desertification, and halt and reverse land degradation and halt biodiversity loss

Figure 1 Grouping SD goals by focus on achieving globally significant results (hereinafter, goal numbers are denoted by the letter $\mathrm{G}$ with the addition of a number indicating the ordinal number of the goal in accordance with their list given in [7]).

A significant effect will be provided due to the use of modern IT, including cloud technologies, the Internet of things, optimization of transport planning [10]. However, the problem of achieving SD goals is the lack of a reliable and generally accepted system for monitoring information on the status of indicators of achieving these goals. For example, it was found that indicators of water supply and sanitation security are not taken into account. The situation is similar with indicators of achievement of other goals, which casts doubt on the success of the implementation of UN program documents on the SD problem [11].

Other humanitarian and sociopolitical goals are indirectly associated with the implementation of logistically sound management decisions.

\subsection{Mechanisms and Directions of the Impact of Logistics on Sustainable Development}

In modern postindustrial society, the theory of which was developed by Alvin Toffler (1928 - 2016), Daniel Bell (1919 - 2011), Peter Drucker (1909 - 2005), etc., the leading social class is the cognitariat - a community of educated people who create the knowledge economy. In the United States, the share of those employed in industrial production is no more than $10 \%$, while in the service sector it has reached $80 \%$. The labor of cognitaries turned knowledge into the main productive force, providing up to $80 \%$ of GDP. Modern IT, biotechnology, nanotechnology became a visual material embodiment of the new economy. Human capital currently forms the foundation of all production activities [12]. A multiple increase in the volume of consumed resources with a simultaneous increase in the average distance of them transportation has actualized logistics as the main means of reducing the transport component of the cost of production.

The expert-logical analysis carried out by the authors made it possible to subdivide the impact of logistics on the achievement of SD goals into direct and indirect.

A direct impact occurs in cases where logistically significant management decisions have a direct impact on indicators that serve as indicators of achievement of SD goals. For example, this is observed when rationalizing routes for transporting agricultural goods and food products, as well as minimizing warehouse operations for the temporary storage of the corresponding commodity mass. Logistics of transportation and storage of these goods 
significantly reduces losses during transportation, storage, transshipment and transshipment of goods between various vehicles and warehouse terminals. According to the authors, in the former USSR, up 30\% of the mass of agricultural products shipped by producers was lost in the distribution network due to neglect of logistic in favor of the for the notorious planned economy. As a result, for example, the Soviet Union produced a significant share of the grain crops consumed. The transition to market principles of management made it possible to eliminate the problem of grain deficit in Russia in two years. The country has turned from an exporter to an importer of grain.

The mechanisms of the direct influence of logistics on the achievement of SD goals are shown in Table. 1.

The indirect impact of logistics is observed in cases where the corresponding links to the achievement of a specific SD goal are not obvious. For example, the positive impact of logistics on achieving gender equality is not obvious (G 5).

The transport and logistics industry have the most significant impact on society, the economy, social relations and creates a serious burden on the environment. 882 publications from the Web of Science database for 20192020 were analyzed. The use of frequency analysis made it possible to identify the main areas of research. There are the next areas sustainable transport development and planning, rationalization of supply chains, assessment of the efficiency of transport activities taking with account social and environmental consequences [13].

The development of logistics leads to an increase in the availability of various territories and objects of production and economic activity. Many routine processes, which were previously performed with the use of cheaper labor, begin to be carried out using modern technologies that require an increase in the level of human capital of workers, the development of education, and the mastery of IT. The labor of professionals is becoming in demand in such jobs, the replacement of "muscles" with intellectual labor expands the possibilities of using female labor (and women, as you know, are more accurate and attentive workers than the stronger sex). Of course, logistics is unable to fully address the problem of inequality of people. But, according to expert judgment, its contribution to the achievement of this goal SD can recoup up to $3-5 \%$ of the total "background" invested resources allocated to achieve goal G 5 . Therefore, we can figuratively say that logistics is an agent of influence in the interests of achieving goal $\mathrm{G} 5$.
Table 1. Direct influence of logistics on the achievement of SD targets.

\begin{tabular}{|c|c|}
\hline $\begin{array}{l}\text { Targets } \\
\text { of SD }\end{array}$ & $\begin{array}{l}\text { Causal relationships that ensure the achievement } \\
\text { of this goal through the implementation of } \\
\text { logistically sound decisions }\end{array}$ \\
\hline G1 & $\begin{array}{l}\text { Logistization ensures the availability of territories } \\
\text { and resources, which directly increases the } \\
\text { potential for growth in the well-being of the } \\
\text { population }\end{array}$ \\
\hline G2 & $\begin{array}{l}\text { Logistics helps to accelerate and reduce the cost } \\
\text { of food supplies, reduce their losses during } \\
\text { transportation and storage, and provides transport } \\
\text { links for producers and sellers of food }\end{array}$ \\
\hline G3 & $\begin{array}{l}\text { Logistics is aimed at increasing the accessibility } \\
\text { of territories and facilities for all persons, } \\
\text { reducing transport injuries }\end{array}$ \\
\hline G6 & $\begin{array}{l}\text { Energy logistics provides water supply. Medical } \\
\text { logistics ensures waste disposal and sanitation }\end{array}$ \\
\hline G7 & $\begin{array}{l}\text { Energy logistics ensures everyone has access to } \\
\text { energy }\end{array}$ \\
\hline G8 & $\begin{array}{l}\text { Logistics ensures economic growth by reducing } \\
\text { costs in the field of circulation of commodity } \\
\text { mass }\end{array}$ \\
\hline G9 & $\begin{array}{l}\text { Logistics itself is a framework for the formation } \\
\text { of material infrastructure }\end{array}$ \\
\hline G 10 & $\begin{array}{l}\text { Logistics is aimed at rationalizing material flows } \\
\text { of resources, including international and domestic } \\
\text { transport, which ensures equal accessibility of all } \\
\text { territories }\end{array}$ \\
\hline G11 & $\begin{array}{l}\text { Safe and sustainable cities are formed due to the } \\
\text { logistics of transport flows and minimization of } \\
\text { the costs of storing material and material } \\
\text { resources }\end{array}$ \\
\hline G12 & $\begin{array}{l}\text { Logistics increases the sustainability of } \\
\text { production, consumption and waste disposal }\end{array}$ \\
\hline G13 & $\begin{array}{l}\text { Logistics in general minimizes the volume of } \\
\text { transport work and warehouse storage, which } \\
\text { automatically leads to a reduction in energy costs } \\
\text { per unit of production and thermal pollution of the } \\
\text { environment }\end{array}$ \\
\hline
\end{tabular}

Similar arguments can be used for regard to the influence of logistics on other indirectly related SD goals.

\section{DISCUSS AND CONCLUSION}

Comparison of each of the SD goals with the results of logistically sound management decisions allows us to conclude that such decisions always contribute to the achievement of sustainable development goals. This is primarily true for economically significant goals, goals related to environmental well-being and food security. The impact of logistics on the achievement of sociopolitical goals of sustainable development is manifested indirectly. Improving logistics always contributes to the sustainable development of countries, territories and industrial complexes. 
Modern IT provides innovative results of building sustainable logistics systems and supply chains based on large databases. The study of numerous publications on this area of logistics development, presented in [14], showed trends in the formation of supply chains, identified existing gaps and topical directions for further research

To facilitate the logistics of the economy and the entire system of public relations, as well as to ensure the implementation of the SD concept, proper qualification training of specialists in various sectors of the national economy is important. The innovative moments in such training are the development of eco-consciousness and understanding of the fundamentals of cognitive economics by specialists $[15,16]$.

An urgent scientific and practical task for modern researchers and designers of various socio-economic and transport systems is to establish the quantitative effect of the introduction of logistically sound management decisions on increasing the stability of the functioning of these systems.

\section{REFERENCES}

[1] I. V. Spirin, O. Yu. Matantseva, Yu. M. Grishaeva, M. I. Savosina, Planning of passenger transportation in the cities of Russia on the basis of sustainable development. In IOP Conference Series: Materials Science and Engineering ICI2AE-2019, 2019, 632, 012053. DOI: https://doi.org/10.1088/1757899X/632/1/012053.

[2] Sustainable development in Russia. Eds. S. Bobylev and R. Perelet, Berlin - St. Petersburg, RussianGerman Environmental Information Bureau, 2013, p. 203.

[3] I. V. Spirin I. V., Yu. M. Grishaeva, S. N. Glazachev, M. I. Savosina, Yu. V. Shumilov, Sustainable development of urbanization. In Astrakhan bulletin of environmental education, 6(54) (2019) pp. 75-85.

[4] Report of the UN Conf. on environment and development. Rio de Janeiro, Brazil, 3-14 June 1992, Vol. I, A/CONF.151/26. https://www.un.org/en/development/desa/populatio $\mathrm{n} /$ migration/generalassembly/docs/globalcompact/ A_CONF.151_26_Vol.I_Declaration.pdf.

[5] The future we want. UN Conf. on sustainable development RIO+20. Agenda item 10, Outcome of the conference Rio de Janeiro, Brazil, 20-22 June 2012 ,

A/CONF.216/L.1. https://sustainabledevelopment.un.org/rio20.

[6] E. Suzanne, N. Absi, V. Borodin, Towards circular economy in production planning: Challenges and opportunities. In: European journal of operational research, 287(1) (2020) pp. 168-190. DOI: https://doi.org/10.1016/j.ejor.2020.04.043.

[7] Full report of the Open working group of the General Assembly on Sustainable development goals is issued as document $\mathrm{A} / 68 / 970,2015$. http://undocs.org/A/68/970

[8] C. Mio, S. Panfilo, B. Blundo, Sustainable development goals and the strategic role of business: a systematic literature review, Business strategy and the environment, Jul. 2020. DOI: https://doi.org/10.1002/bse.2568.

[9] M. I. Savosina, Logistic aspects of sustainable development of territories. In: Sat. Proceedings of the International Scientific and Practical Conference "Dobrodeevsky Readings - 2018", Moscow, MRSU, 2018, pp. 121-124.

[10] T. B. Cetrulo, R. C. Marques, T. F. Malheiros, N. M. Cetrulo, Monitoring inequality in water access: Challenges for the 2030 Agenda for sustainable development, Science of the total environment, 2020, 727, $138746 . \quad$ DOI: https://doi.org/10.1016/j.scitotenv.2020.138746.

[11] M. S. Mahapatra, B. Mahanty, India's national food security programme: a strategic insight. In: Proceedings of Sadhana-Acfdemy in engeneering sciences, UNSP, 2018, 43(12), 194. DOI: https://doi.org/10.1007/s12046-018-0947-2

[12] I. V. Spirin, Yu. M. Grishaeva, O. Yu. Matantseva, Z. N. Tkacheva, Human capital as a tool of ensuring sustainable development. In: Proceeding of The Int. science and technology conference "FarEastCon 2020", Vladivostok, Russian Federation, Eds. Solovev, D.B. et al., Far Eastern Federal University, Publisher Springer Singapore, Series title Smart Innovation, Systems and Technologies, 2021, 227, pp. 709-714. DOI: https://doi.org/10.1007/978-98116-0953-4-69.

[13] X. B. Zhao, Y. J. Ke, J. Zuo, W. Xiong, P. Wu, Evaluation of sustainable transport research in 2000-2019. In: Journal of cleaner production, 2020 256, 120404.2 DOI: https://doi.org/10.1016/j.jclepro.2020.120404

[14] C. J. C. Jabbour, P. D. C. Fiorini, M. Queiroz, N. O. Ndubisi, Digitally-enabled sustainable supply chains in the 21st century: A review and a research agenda. In: Science of the total environment, 725, 138177.

DOI: https://doi.org/10.1016/j.scitotenv.2020.138177.

[15] Y. S. Shim, D. C. Bellomy, Thinking and acting systematically about the Anthropocene. In: Systemic Practice and Action Research, 31(6) (2018) pp. 599-615. DOI: https://doi.org/10.1007/s11213-018-9442-2. 
[16] Yu. M. Grishaeva, I. V. Spirin, O. Yu. Matantseva, Aspects of Professional Education in the Higher School in the Interests of the Techno-Sphere Safety. In: Modern Research of Social Problems (Online Scientific Journal), 9(65) (2016) pp. 5-18. DOI: https://doi.org/10.12731/2218-7405-2016-9-5-18. 